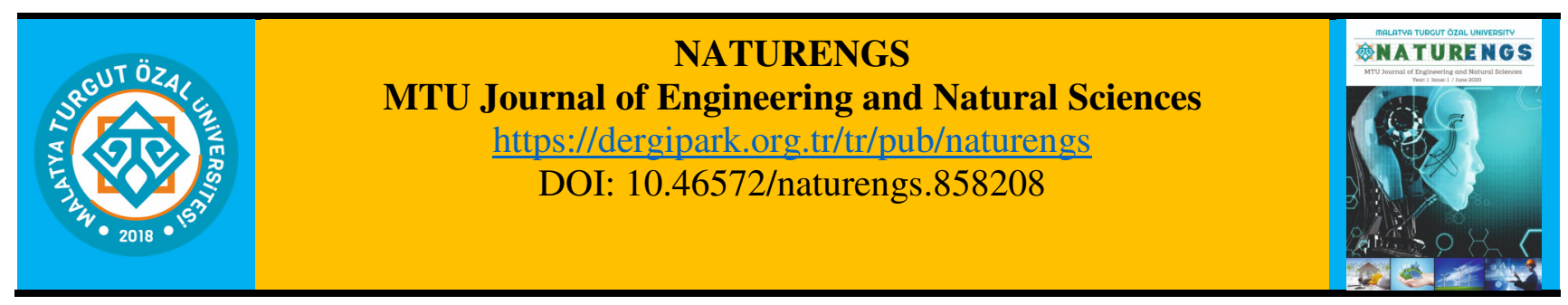

Research Article

\title{
The Usage of Mg - Metal Chlorides in Hydrogen Generation
}

\author{
Begüm Esra AYTAŞ ${ }^{1 *}$, Sevim YOLCULAR KARAOĞLU² \\ ${ }^{1}$ Materials Science and Engineering Department, Graduate School of Applied and Natural Science Ege \\ University, İzmir, Turkey. \\ ${ }^{2}$ Chemical Engineering Department, Engineering Faculty, Ege University, İzmir, Turkey.
}

(Received: 11.01.2021; Accepted: 09.05.2021)

\begin{abstract}
The reaction of metals with water is one of the hydrogen generation methods. $\mathrm{Mg}$ stands out as a viable alternative when compared to other metals for producing hydrogen. However, the emergence of $\mathrm{Mg}(\mathrm{OH})_{2}$, which interrupts hydrogen production in its reaction with water, has led to the search for new methods to improve the hydrogen production process. For this reason, in our study, chloride salts $\left(\mathrm{CoCl}_{2}\right.$ and $\left.\mathrm{AlCl}_{3}\right)$ have been used to improve hydrogen generation. The composites have been prepared with the addition of different chlorides $\left(\mathrm{AlCl}_{3}\right.$ and $\mathrm{CoCl}_{2}$ ) into $\mathrm{Mg}$ with ball milling. $\mathrm{AlCl}_{3}$ and $\mathrm{CoCl}_{2}$ have been used separately and together while forming $\mathrm{Mg}-$ metal composite powder. Powder mixtures have been grounded by a planetary ball mill at different times ( 2 and 4 hours). Deformations, which are thought to contribute positively to the reaction, have been obtained on the metal surface with ball milling. The microscopic images of the powder mixtures have been analyzed by SEM. In addition, distilled water, acetic acid and citric acid have been used in our study to observe the effects of hydrogen production. When distilled water has been used with powder mixtures in the hydrogen generation experiments, a minimal amount of hydrogen gas output has been observed. It has been observed that the use of acetic acid or citric acid solutions significantly enhances the amount of hydrogen formed. 4 hours milled $\mathrm{Mg}-10 \mathrm{wt} \% \mathrm{CoCl}_{2}$ composite has the best hydrolysis properties for all experiments with its $138 \mathrm{ml}$ of hydrogen generation at $30^{\circ} \mathrm{C}$ in $30 \mathrm{ml}, 2 \mathrm{M}$ citric acid solution.
\end{abstract}

Keywords: Mg, Hydrogen production, Mg- metal chloride composites, Ball milling.

\section{INTRODUCTION}

Environmental pollution that occurs while producing and consuming energy is an important issue. The negative effects of these issues threaten our future. The energy demand is rising with the increasing population, technology, and standard of living in the world [1]. For the time being, this energy demand is mostly provided by fossil fuels [2]. However, the use of conventional fossil fuels causes vigorously pollution of the environment [3]. So, the decline of the non-renewable energy reserves has accelerated the search for alternative and renewable energy sources [4].

Hydrogen has attracted great attention in recent years due to its high energy carrier potential and environmentally friendly end product [5]. Hydrogen is a carrier of energy. The chemical energy releases from two hydrogen bonds as a result of combustion and only water forms as a by-product. The energy content of hydrogen $(120 \mathrm{MJ} / \mathrm{kg})$ is quite high compared to gasoline $(44 \mathrm{MJ} / \mathrm{kg}$ ) [6]. Today, the use of hydrogen as a fuel is rising day by day. The vehicles that may be operated with hydrogen fuel cells are almost three times more efficient than gasoline-

*Corresponding Author: begume.aytas@gmail.com

ORCID number of authors: ${ }^{10000-0003-3528-208 X},{ }^{2} 0000-0003-0954-6889$ 
powered engines [7]. It is expected that hydrogen fuel cells will be used widely in the future and therefore environmental pollution will be lowered.

Hydrogen can be produced by different methods such as steam reforming of hydrocarbons, electrolysis of water, gasification of heavy oil, coal or biomass [8]. However, the manufacturing of hydrogen by fossil fuels is ineffectual and unsustainable applications which cause releasing of pollutants and harmful gases such as $\mathrm{NO}_{\mathrm{x}}, \mathrm{SO}_{\mathrm{x}}$, etc. and also increase $\mathrm{CO}_{2}$ emissions [9]. The significant point is the use of clean and inexpensive energy sources while obtaining hydrogen [10]. For this purpose, many scientific types of research focus on hydrogen generation by using metals $[4,11]$, metal hydrides [12] and their alloys [13].

Most of the laboratory studies have been used active metals such as $\mathrm{Mg}$ [5, 8], $\mathrm{Al}$ [4], $\mathrm{Li}$ [14, 15], borohydrides such as $\mathrm{NaBH}_{4}$ [16] and metal hydrides such as $\mathrm{LiAlH}_{4}$ [17], etc. In particular, $\mathrm{Al}$ and $\mathrm{Mg}$ were preferred in most of the studies because of their high activity and low toxicity $[4,5,8,18]$.

Hydrogen can be obtained as a result of the following reaction between solid magnesium with water:

$\mathrm{Mg}(\mathrm{s})+2 \mathrm{H}_{2} \mathrm{O}(\mathrm{l}) \rightarrow \mathrm{Mg}(\mathrm{OH})_{2}+\mathrm{H}_{2}(\mathrm{~g})$

$\mathrm{Mg}$ based systems provide high $\mathrm{H}_{2}$ yield in the presence of water and activator. $\mathrm{H}_{2}$ conversion from aqueous solutions is based on the cathodic/anodic reaction of $\mathrm{H}^{+}$or $\mathrm{H}_{2}$ molecules in $\mathrm{H}_{2} \mathrm{O}$ and a highly interactive material $[10,19]$ :

Cathodic reactions:

$2 \mathrm{H}_{2} \mathrm{O}+2 \mathrm{e}-\rightarrow \mathrm{H}_{2}+2 \mathrm{OH}-$

and/or

$2 \mathrm{H}^{+}+2 \mathrm{e}-\rightarrow \mathrm{H}_{2}$

Anodic reactions:

$\mathrm{Mg} \rightarrow \mathrm{Mg}^{2+}+2 \mathrm{e}-$

It was observed that the reaction rate increased in a highly corrosive environment. In various scientific studies, it has been stated that acids [8, 10, 20], saline solutions [8, 14, 19, 21] and seawater [18] are used by the researchers to improve the hydrogen yield.

Organic acids such as citric acid $\left(\mathrm{C}_{6} \mathrm{H}_{8} \mathrm{O}_{7}\right.$, molar mass: $\left.192.124 \mathrm{~g} / \mathrm{mole}\right)$ and acetic acid $\left(\mathrm{CH}_{3} \mathrm{COOH}\right.$, molar mass: $\left.60.052 \mathrm{~g} / \mathrm{mole}\right)$ have been reported as accelerate the rate of hydrogen production [22]. The following equation shows the hydrolysis reaction with using acetic acid and citric acid:

$$
\begin{aligned}
& 2 \mathrm{Mg}(\mathrm{s})+2 \mathrm{H}_{2} \mathrm{O}(\mathrm{l})+2 \mathrm{CH}_{3} \mathrm{COOH}(\mathrm{l}) \rightarrow \mathrm{Mg}(\mathrm{OH})_{2}(\mathrm{aq})+\mathrm{Mg}\left(\mathrm{CH}_{3} \mathrm{COO}\right)_{2}(\mathrm{aq})+2 \mathrm{H}_{2}(\mathrm{~g}) \\
& 2 \mathrm{Mg}(\mathrm{s})+2 \mathrm{H}_{2} \mathrm{O}(\mathrm{l})+\mathrm{C}_{6} \mathrm{H}_{8} \mathrm{O}_{7}(\mathrm{~s}) \rightarrow \mathrm{Mg}(\mathrm{OH})_{2}(\mathrm{aq})+\mathrm{C}_{6} \mathrm{H}_{8} \mathrm{MgO}_{7}(\mathrm{aq})+\mathrm{H}_{2}(\mathrm{~g})
\end{aligned}
$$

Acetic acid and citric acid have been preferred because they are easily accessible, promote hydrogen production, do not produce toxic end products, do not harm to the health and environment while using in the experiments [20]. End of the reactions between $\mathrm{Mg}$ and acetic acid solution forms $\mathrm{Mg}\left(\mathrm{CH}_{3} \mathrm{COO}\right)_{2}$ (magnesium acetate) which can be used food additive in industrial processes [23]. The reaction between $\mathrm{Mg}$ and citric acid solution results in the $\mathrm{C}_{6} \mathrm{H}_{8} \mathrm{MgO}_{7}$ (magnesium citrate) salt [24]. This substance is used as an additive in the pharmaceutical and food industry. 
$\mathrm{Mg}$ [11], $\mathrm{MgH}_{2}$ [12], $\mathrm{Mg}_{2} \mathrm{Si}$ [13], various Magnesium Borohydrides such as $\mathrm{Mg}\left(\mathrm{BH}_{4}\right)_{2} .2 \mathrm{NH}_{3}$ [17], $\mathrm{Mg}\left(\mathrm{BH}_{4}\right)_{2}$ [5], $\mathrm{Mg}$ nanopowder [25] and waste $\mathrm{Mg}$ shavings [8] are used as the source of hydrogen production with $\mathrm{Mg}$.

Researchers have submitted some physical and chemical procedures for improving hydrogen generation such as ball milling [14, 21, 26-28], using carbon materials [29], usage of catalyst [30], arc plasma method [25], two-step water splitting method [31], etc.

However, the most effective methods for generating hydrogen are ball milling which has been performed on various metals such as $\mathrm{Mg}$ and $\mathrm{Al}$ and their hydrides and composites for hydrogen generation by hydrolysis $[8,26]$.

In our study, for optimizing the hydrogen generation, the effects of the ball milling method, the use of the metal chlorides $\left(\mathrm{CoCl}_{2}\right.$ and $\left.\mathrm{AlCl}_{3}\right)$ which forms composite with $\mathrm{Mg}$ at various grinding times ( 2 and 4 hours), the content of the solutions in which the experiments took place were investigated. The initial experiments were carried out at $60^{\circ} \mathrm{C}$ using $30 \mathrm{ml}$ of distilled water, $0.24 \mathrm{~g}$ of powder and a magnetic stirrer. To observe the effect of the acid solutions on the $\mathrm{Mg}(\mathrm{OH})_{2}$ layer which disrupted the reaction, experiments were also carried out with stirring, using $30 \mathrm{ml}$ of $1 \mathrm{M}$ and $2 \mathrm{M}$ acetic acid and citric acid solutions and using $0.12 \mathrm{~g}$ of composite powders at $30^{\circ} \mathrm{C}$. The effects of the acid solution type and variating milling time on hydrogen production have been investigated. Characterization of composite materials was carried out by SEM (Carl Zeiss 300VP) analysis. The results were compared with each other.

\section{MATERIALS AND METHOD}

\subsection{Materials}

$\mathrm{Mg}$ was purchased from Merck with $99 \%$ purity. The components, $\mathrm{AlCl}_{3}$ (99.99\% Merck), $\mathrm{CoCl}_{2}$ (98\%, Merck) have been milled with $\mathrm{Mg}$. Distilled water has been used for hydrolysis experiments, preparing solutions and diluting acetic acid. In the first experiments, distilled water has been used for hydrolysis. Acetic acid (100\% purity, Merck) and citric acid monohydrate (8.7\% water include was purchased from Weifang Ensign Industry Co.) have been used for creating an acidic medium.

\subsection{Method}

\subsubsection{Preparation of powder mixtures}

The effect of using different metal chlorides on hydrogen production has been observed in the experiments. In addition, the effect of changing the weight percentages of chlorides in $\mathrm{Mg}$ composite and changing the milling times have been investigated. The metal chlorides used in the preparation of the composites, the weight percentages of the chlorides in the composites and the milling times have been represented in Table 1. 
Table 1. The contents and the milling times of $\mathrm{Mg}$-metal composites.

\begin{tabular}{|c|c|c|c|}
\hline $\begin{array}{c}\text { Mg amount in } \\
\text { the composite } \\
(\mathbf{w t} \%)\end{array}$ & $\begin{array}{c}\text { Metal chloride amount } \\
\text { in the composite } \\
(\mathbf{w t} \%)\end{array}$ & $\begin{array}{c}\text { The metal chloride } \\
\text { content of the } \\
\text { composite }\end{array}$ & $\begin{array}{c}\text { Milling time } \\
\text { (h) }\end{array}$ \\
\hline 90 & 10 & $\mathrm{CoCl}_{2}$ & 2 \\
\hline 95 & 5 & $\mathrm{CoCl}_{2}$ & 2 \\
\hline 90 & $5+5$ & $\mathrm{CoCl}_{2}+\mathrm{AlCl}_{3}$ & 2 \\
\hline 95 & $2.5+2.5$ & $\mathrm{CoCl}_{2}+\mathrm{AlCl}_{3}$ & 4 \\
\hline 90 & 10 & $\mathrm{CoCl}_{2}$ & 4 \\
\hline 95 & 5 & $\mathrm{CoCl}_{2}$ & 4 \\
\hline 90 & $5+5$ & $\mathrm{CoCl}_{2}+\mathrm{AlCl}_{3}$ & 4 \\
\hline 95 & $2.5+2.5$ & $\mathrm{CoCl}_{2}+\mathrm{AlCl}_{3}$ & 4 \\
\hline
\end{tabular}

\subsubsection{Preparing composites by ball milling}

The composites have been used to compare the results using different grinding durations and amounts of salts on hydrogen production. Stainless steel vials and balls have been used in the milling process. The balls were about 200 grams and the powder-to-ball mass ratio was 1:20. The maximum milling time was 4 hours. Longer grinding times have not been preferred for energy and time-saving. For the milling process, ECO planetary ball miller ( $200 \mathrm{rpm}, 25 \mathrm{Hertz}$ ) has been used.

\subsubsection{Performing the experiments}

For the experiments, a three-necked $(250 \mathrm{ml})$, round bottom glass reactor has been used. The reactor has been placed into a magnetic stirrer heater (Figure 1). The connection of the reactor and a glass measuring cylinder $(250 \mathrm{ml})$ that was suspended by inverting in a half-full beaker, has been made using a $400 \mathrm{~mm}$ long $8 \mathrm{~mm}$ inner diameter pipe. Hydrogen formed in the reactor, which passed through the pipe and cooled with water at room temperature, has been collected in the measuring cylinder. Hydrogen production has been recorded with the help of the measuring cylinder. The water displacement procedure has been used for measuring the amount of produced hydrogen.

The experiments have been carried out in distilled water, $1 \mathrm{M}$ and $2 \mathrm{M}$ citric acid and acetic acid solutions, respectively. Each test has been repeated at least twice, and the margin error has been accepted as $< \pm 5 \%$ in the experiments. Each hydrogen generation experiment has been observed for one hour. 


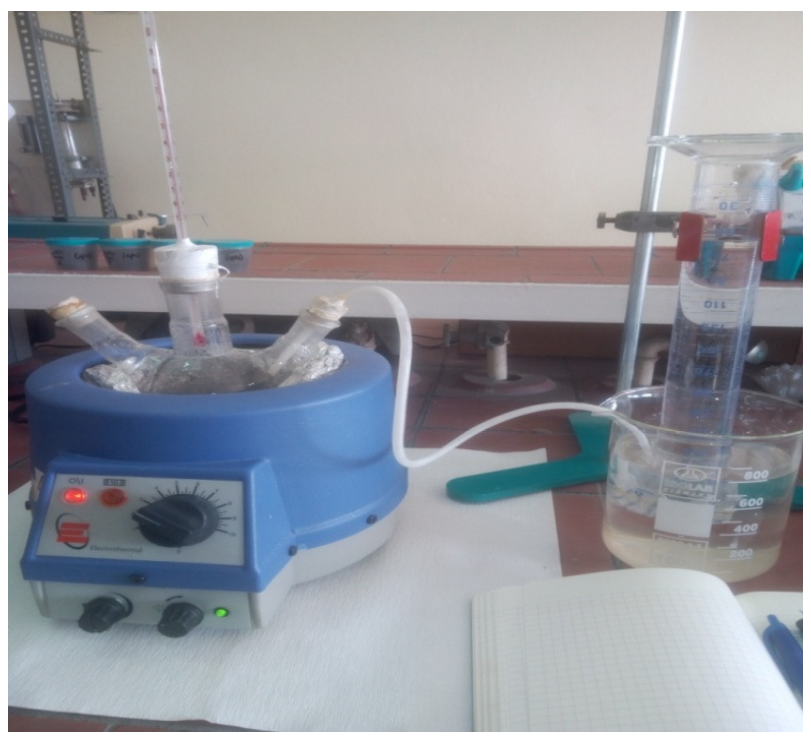

Figure 1. Experimental setup

\section{RESULTS AND DISCUSSION}

It is well known that the reaction between $\mathrm{Mg}$ and water causes hydrogen generation [26]:

$\mathrm{Mg}(\mathrm{s})+2 \mathrm{H}_{2} \mathrm{O}(\mathrm{l}) \rightarrow \mathrm{Mg}(\mathrm{OH})_{2}+\mathrm{H}_{2}(\mathrm{~g})$

In our study gas output has not been observed when distilled water and other solutions have been used with non-milling Mg to obtain hydrogen. The biggest handicap of this reaction is that the formed hydroxide layer discontinues the reaction. To eliminate this formed hydroxide layer, different weights of metal chlorides have been used together with $\mathrm{Mg}$. The ball milling method has been preferred to create $\mathrm{Mg}$ - metal chloride composites. The formed $\mathrm{Mg}$-metal chloride composites have been reacted with distilled water, and acidic (acetic acid and citric acid) solutions to observe hydrogen production. The effects of the ball milling in the production of hydrogen, the use of metal chlorides and the interaction of Mg-metal chloride composite materials with different solutions have been studied also in the Master's Thesis [27].

It is widely recognized that the repeated grinding process in ball-milling changes microstructure, distribution of the components and formation. It is submitted that combining these defects may support also metal corrosion. The effects of the ball-milling process on powder mixtures have been observed with the help of SEM images (Carl Zeiss 300VP). The original material was $\mathrm{Mg}$ powder (Figure 2) which had a relatively smooth surface, which after milling, became irregular and exhibited breakdown in the powder surface. In the literature studies, it is seen that the milling of $\mathrm{Mg}$ with solid salts is very effective for improving the hydrolysis reactivities. The salt additive is generally reported to act as a process control agent in the milling process which increases the specific surface area of $\mathrm{Mg}$ powder [11, 14, 19, 29]. 


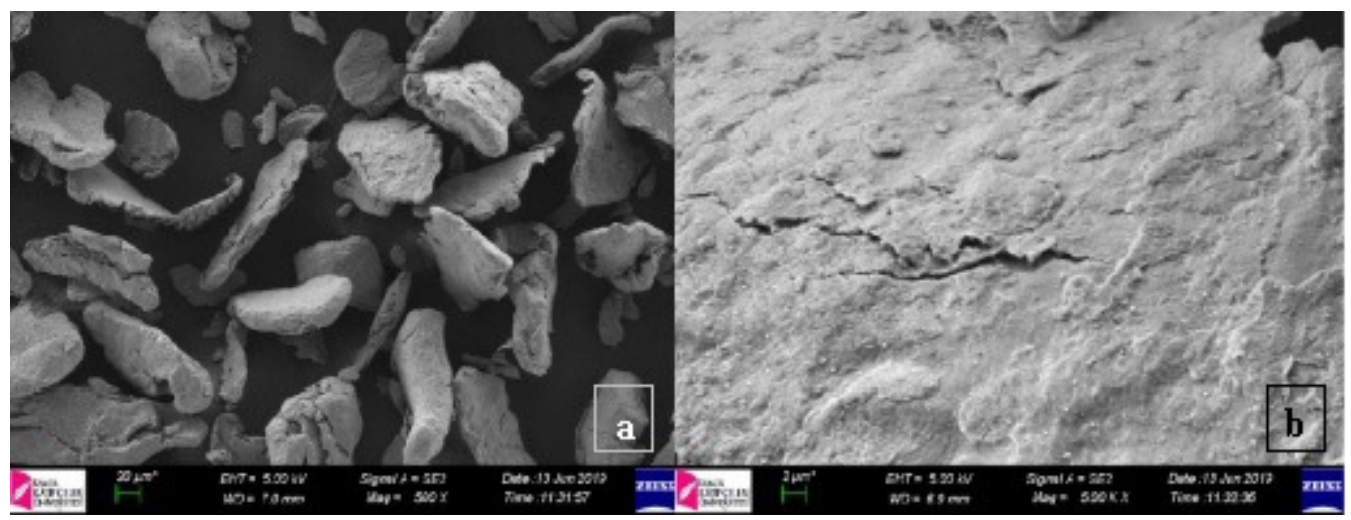

Figure 2. SEM images of Mg powder without milling a) and b) with different magnifications.

The ball-milling time is a very important parameter that affects hydrogen generation. Various changes have been observed with increasing milling time in the composite material subjected to milling. One of the most important of these changes is the slow reduction of the powder mixture which causes an increase in the surface area. It has been considered that 2 hours of milling caused a noticeable increase in the surface area of the powder (Figure 3).

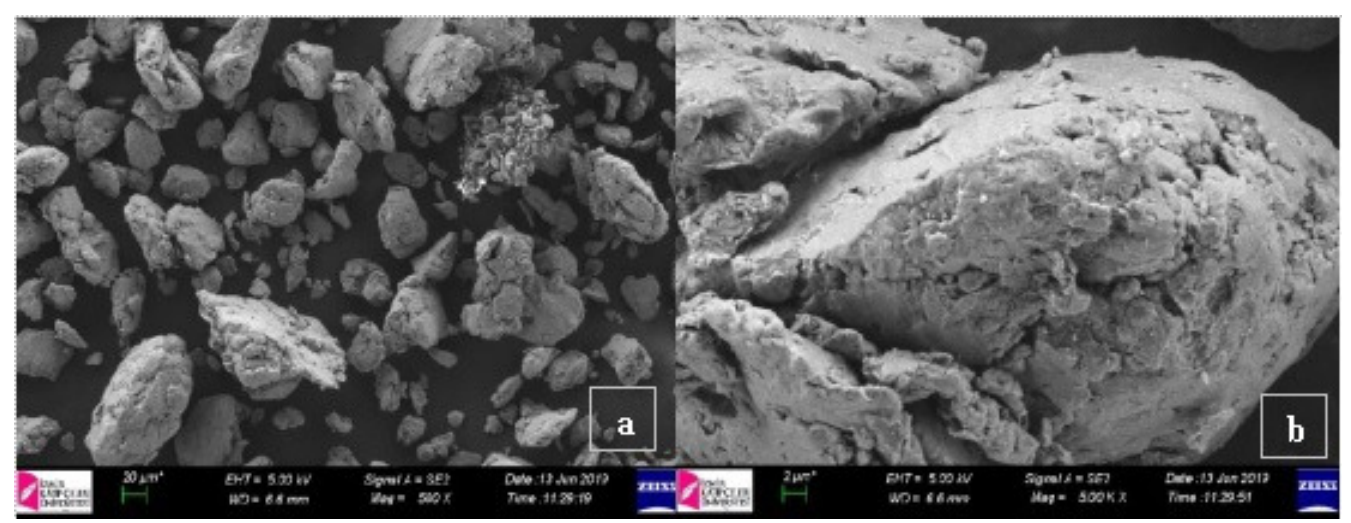

Figure 3. SEM images of $10 \mathrm{wt} \% \mathrm{CoCl}_{2}-90 \mathrm{wt} \% \mathrm{Mg}$ composite with $2 \mathrm{~h}$ milling time, a) and b) with different magnifications

Another change is that the milling process causes deformations on the surface of the material, thereby increasing the formation of fresh surfaces. Increased surface deformation can be observed in 4 hours milled $10 \mathrm{wt} \% \mathrm{CoCl}_{2}-90 \mathrm{wt} \% \mathrm{Mg}$ composite (Figure 4), compared to 2 hours milled same powder and unmilled $\mathrm{Mg}$ powder. 


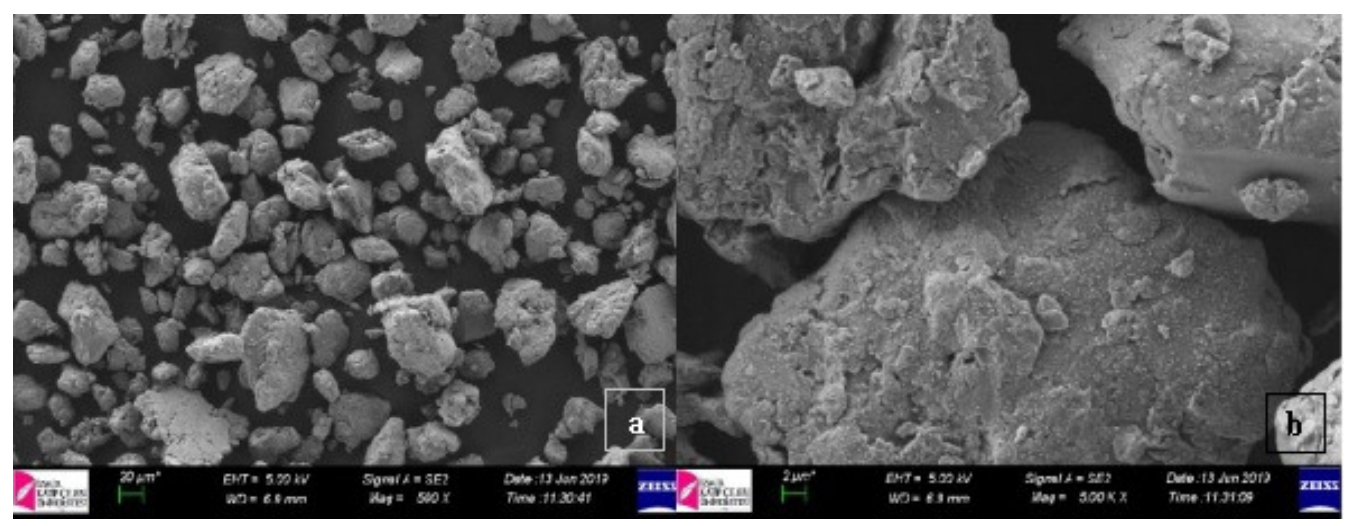

Figure 4. SEM images of $10 \mathrm{wt} \% \mathrm{CoCl}_{2}-90 \mathrm{wt} \% \mathrm{Mg}$ composite with $4 \mathrm{~h}$ milling time, a) and b) with different magnifications

It can also be concluded that metal chloride salts are held onto the surface of $\mathrm{Mg}$ powder during milling (Figure 5). Prolonged milling of $\mathrm{Mg}$-containing powders may result in cold welding and agglomeration of the particles, as opposed to reducing the particle size [21, 26]. For this reason and to save energy, milling times 2 and 4 hours have been selected, longer milling times have not been preferred.

The weight percentage of metal chloride in Mg-metal chloride composite is the other important parameter. Although the cold welding predominated on ductile $\mathrm{Mg}$, the addition of chlorides such as $\mathrm{CoCl}_{2}$, and $\mathrm{AlCl}_{3}$ have favored the fracturing of $\mathrm{Mg}$ during the milling process (Figure 5). It may be concluded that adding chloride to the composite and increasing the weight percentage of chloride in the composite may effectively improve the hydrolysis kinetics.

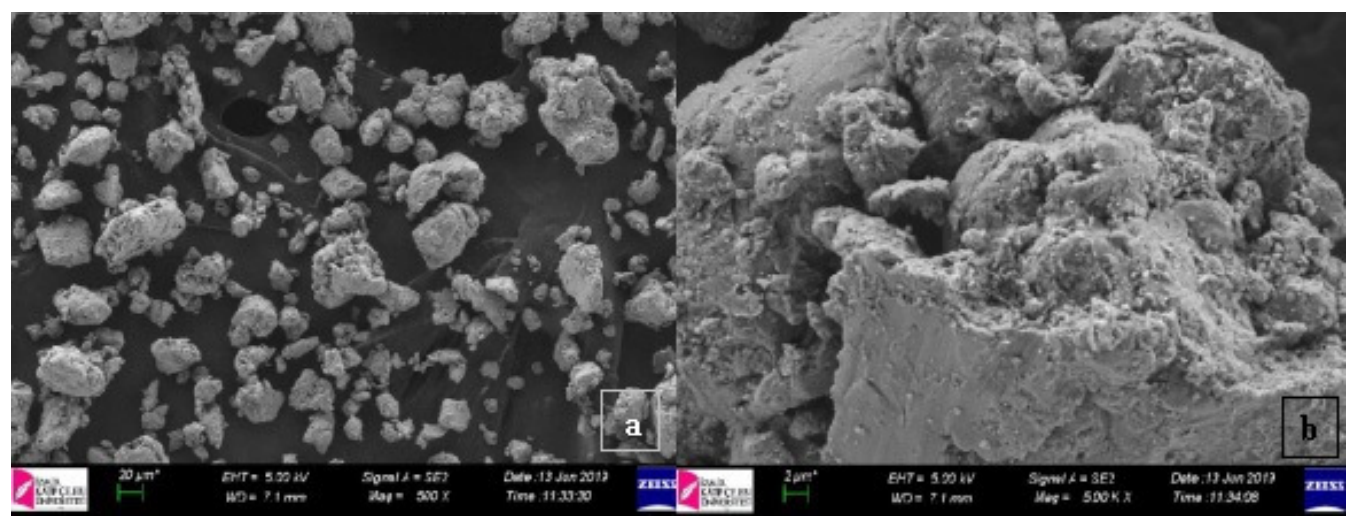

Figure 5. SEM images of $5 \mathrm{wt} \% \mathrm{CoCl}_{2}-5 \mathrm{wt} \% \mathrm{AlCl}_{3}-90 \mathrm{wt} \% \mathrm{Mg}$ composite with $4 \mathrm{~h}$ milling time, a) and b) with different magnifications

$\mathrm{AlCl}_{3}$ is often used for the preparation of aluminum hydroxide and may react with water as the following [14]:

$\mathrm{AlCl}_{3}(\mathrm{~s})+2 \mathrm{H}_{2} \mathrm{O}(\mathrm{l}) \rightarrow \mathrm{Al}(\mathrm{OH})_{3}+3 \mathrm{HCl}(\mathrm{aq})$ 
$223.85 \mathrm{~kJ} / \mathrm{mol}$ heat releases during $\mathrm{AlCl}_{3}$ dissolution. Liu et al. (2012) stated that the $\mathrm{H}^{+}$ions from the generated $\mathrm{HCl}$ may dissolve $\mathrm{Mg}(\mathrm{OH})_{2}$ layer formed from the reaction, thus increasing the fresh $\mathrm{Mg}$ surfaces revealed. So, the large amount of releasing heat and the generating $\mathrm{HCl}$ from $\mathrm{AlCl}_{3}$ dissolution may improve the hydrolysis reaction [14].

In the study of Liu et al.(2013), $3 \mathrm{~mol} \% \mathrm{AlCl}_{3}$ has been added to the $\mathrm{Mg}$ powder and the mixture has been milled for 6 hours. $50 \mathrm{mg}$ powder and $10 \mathrm{ml}$ distilled water has been used. The best result in that study has been recorded as approximately $455.9 \mathrm{ml} . \mathrm{min} /(\mathrm{g} \mathrm{Mg})$. In our study, different milling times and percentage amounts have been used in the experimental study.

Also, a replacement reaction may occur during the ball milling process between $\mathrm{Mg}$ and metal chlorides. After the replacement reaction, the hydrolysis properties of $\mathrm{Mg}$-metal chloride composites may be improved with the electronegativity of the metal element in the chlorides which possibly created a more effectual micro galvanic cell with $\operatorname{Mg}[11,26]$.

Sun et al. (2014) have mentioned that the replacement reaction between $\mathrm{Mg}$ and $\mathrm{CoCl}_{2}$ may occur during the milling process [11]:

$\mathrm{Mg}+\mathrm{CoCl}_{2} \rightarrow \mathrm{MgCl}_{2}+\mathrm{Co}$

Increasing the $\mathrm{CoCl}_{2}$ content of the powder mixture may pioneer a remarkable improvement in hydrogen generation.

In the study of Sun et al.(2014), the different weight percentage of $\mathrm{CoCl}_{2}(2,4,6,8,10 \mathrm{wt} \%)$ has been added to the $\mathrm{Mg}$ powder and the mixture has been milled for 1 hour. $1 \mathrm{~g}$ powder has been used. Powder: Water ratio has been informed as 1:40. The best result in the study has been recorded as $558.6 \mathrm{ml}$. $\mathrm{min} /(\mathrm{g} \mathrm{Mg})$. It may be noted that the results are given in terms of Hydrogen Generation Rate $(\mathrm{ml} . \mathrm{min} /(\mathrm{g} \mathrm{Mg})$ ). In our study, the results have been given in terms of the amount of Hydrogen Generation (ml). Different amounts of powder and the milling times have been used in our experimental studies.

There are many studies in the literature on hydrogen production using Mg-chloride powders. Creating Mg-chloride composites with the ball milling method has made quite noticeable contributions to hydrogen production. In their work, Liu et al. have contributed to the literature by using $\mathrm{CoCl}_{2}$, and Sun et al. with using $\mathrm{AlCl}_{3}$. In our study, the effect of using chlorides separately on hydrogen generation has been given. In addition, we have used also the combination of $\mathrm{CoCl}_{2}$ and $\mathrm{AlCl}_{3}$ salts to observe their effects on hydrogen production in our study. In addition, the reactions of $\mathrm{Mg}$-chloride composites with organic acids and hydrogen recovery have been detailed.

The highest hydrogen formation in $30 \mathrm{ml}$ distilled water at $60^{\circ} \mathrm{C}$ using the $\mathrm{Mg}$ composite containing 5wt $\% \mathrm{CoCl}_{2}+5 \mathrm{wt} \% \mathrm{AlCl}_{3}$ (4 hours milled) has been recorded as $78 \mathrm{ml}$. The use of these two metal chlorides in the $\mathrm{Mg}$ composite may have a synergistic effect. Another remarkable result with 4 hours milled $\mathrm{Mg}+10 \mathrm{wt} \% \mathrm{CoCl}_{2}$ has been recorded as $68 \mathrm{ml}$ of hydrogen gas. Increasing the milling time from 2 hours to 4 hours has been supported by the increase in the amount of hydrogen obtained. Besides, it has been observed that composite powders containing $5 \mathrm{wt} \% \mathrm{CoCl}_{2}$ alone and $2.5 \mathrm{wt} \% \mathrm{CoCl}_{2}+2.5 \mathrm{wt} \% \mathrm{AlCl}_{3}$ with 2 hours milling time were not as effective as the powders containing 10wt\% chlorides for all milling times (Figure 6).

Since chloride ions have a catalytic effect, it may have removed the fresh hydroxide layer formed from the surface of $\mathrm{Mg}$. They may also have a preventive effect on the formation of the new hydroxide layer. In this case, more water molecules may reach the surface, so more hydrogen may be obtained. 


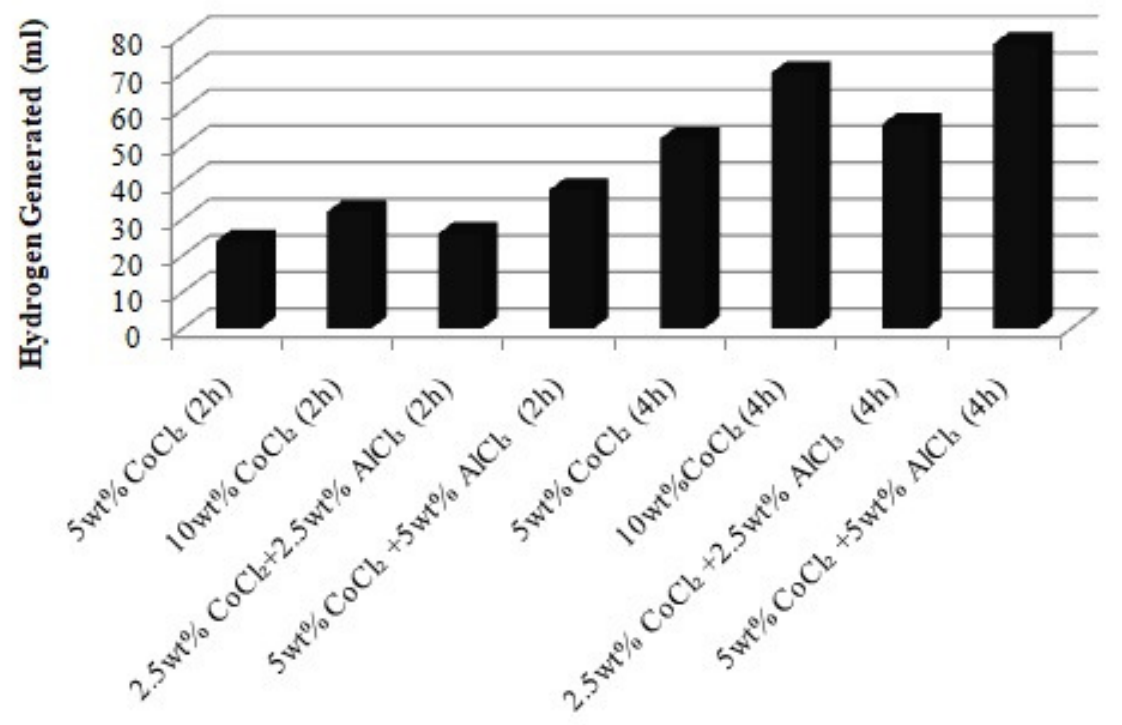

Figure 6. Hydrogen generation with $0.24 \mathrm{~g}$ of powder and $30 \mathrm{ml}$ distilled water at $60^{\circ} \mathrm{C}$.

Acidic solutions have been also used to observe the influence on the hydrogen generation process in this study. Acetic acid and citric acid have been used for creating the acidic medium. To produce $\mathrm{H}_{2}$, the transition of $\mathrm{H}^{+}$ions into the medium should be procured. Therefore, the hydrolysis reaction with using $\mathrm{Mg}$ interrupts quickly and requires an activator. Acids such as metals and chlorides can also be preferred as activators [20]. The use of two different acid solutions (acetic and citric acid) has been acted as an activator in the hydrolysis medium. When $30 \mathrm{ml}, 1 \mathrm{M}$ acid solutions (acetic and citric acid) have been used at even $30^{\circ} \mathrm{C}$, it has been observed that using acid solutions enhanced the hydrogen generation tremendously.

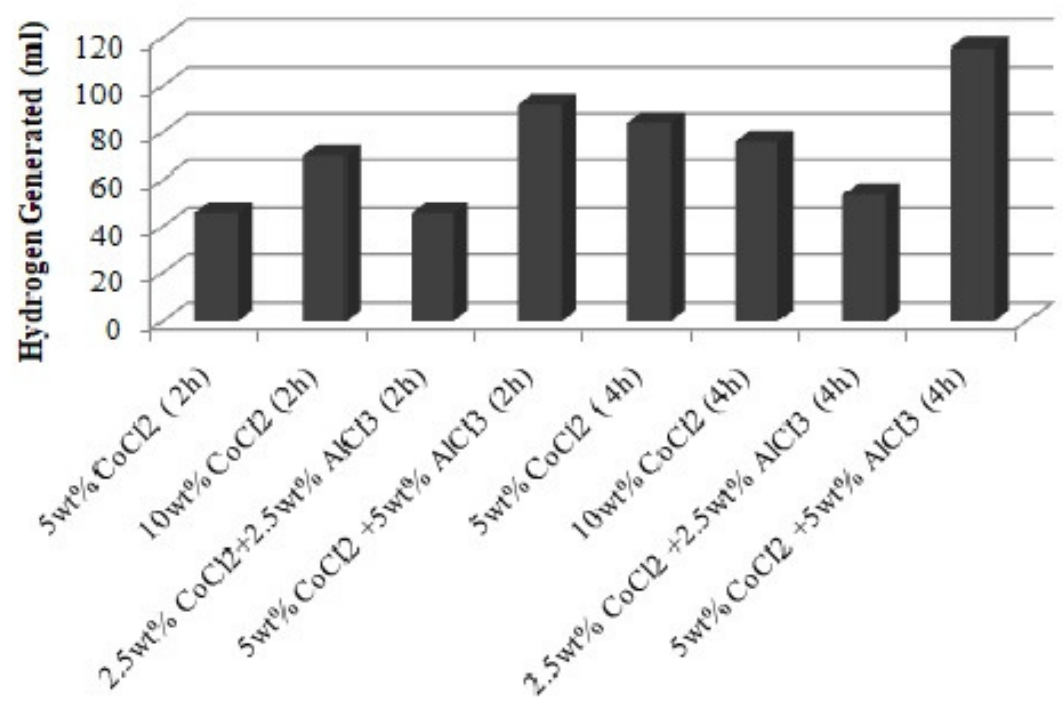

Figure 7. Hydrogen generation with $0.12 \mathrm{~g}$ of powders and $30 \mathrm{ml}, 1 \mathrm{M}$ acetic acid solution. 
The increase in weight percent of $\mathrm{CoCl}_{2}$ in the $\mathrm{Mg}$-metal chloride composite may cause a significant improvement in the generation of hydrogen. Also, it may be seen that the combination of $\mathrm{AlCl}_{3}$ and $\mathrm{CoCl}_{2}$ in $\mathrm{Mg}$-metal chloride composites enhances the hydrolysis properties. Adjusting the total chloride to $10 \mathrm{wt} \%$ may improve hydrogen production as may be seen from the results. 4 hours milled $0.12 \mathrm{~g}$ of $\mathrm{Mg}-5 \mathrm{wt} \% \mathrm{CoCl}_{2}-5 \mathrm{wt} \% \mathrm{AlCl}_{3}$ composite has the best hydrolysis properties with its $116 \mathrm{ml}$ of hydrogen generation for $1 \mathrm{M}$ acetic acid solution (Figure 7).

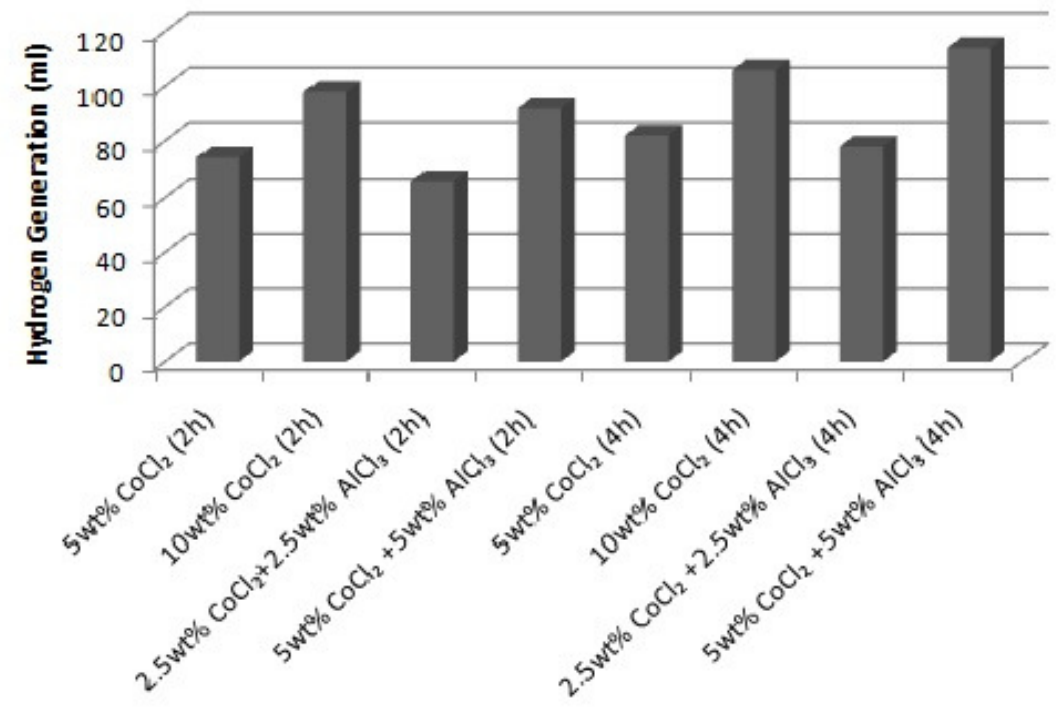

Figure 8. Hydrogen generation with $0.12 \mathrm{~g}$ of powder and $30 \mathrm{ml}, 1 \mathrm{M}$ citric acid solution.

The presence of an acid in the solution may be supported the continuation of the hydrolysis reaction. Acid concentration has an important role in the hydrogen production process when used with $\mathrm{Mg}$-metal chloride composite. It has been noted that when using $\mathrm{CoCl}_{2}$ in samples containing $5 \mathrm{wt} \%$ metal chloride, the maximum hydrogen gas has been released as $82 \mathrm{ml}$. It may be possible to conclude that the use of $10 \mathrm{wt} \%$ metal chloride significantly improves the hydrolysis properties. The positive effect of using $5 \mathrm{wt} \% \mathrm{CoCl}_{2}$ and $5 \mathrm{wt} \% \mathrm{AlCl}_{3}$ together has been reflected in the results. The hydrogen production of this composite structure with a milling time of 4 hours has been enrolled as $114 \mathrm{ml}$ (Figure 8).

The organic acids compared to distilled water may be promising candidates for their contribution to the hydrogen production process. When the concentrations of acetic acid and citric acid solutions have been adjusted to $2 \mathrm{M}$ and the experiments have been repeated to understand the effect of acid concentration on hydrogen production, the obtained results were quite remarkable. Whenever the results of the experiments using $2 \mathrm{M}$ acetic acid solution have been examined, the effect of $\mathrm{Mg}$-metal chloride composite containing the combination of $5 \mathrm{wt} \%$ $\mathrm{CoCl}_{2}$ and $5 \mathrm{wt} \% \mathrm{AlCl}_{3}$ on hydrogen generation can become preeminent. Hydrogen generation has been achieved more than $100 \mathrm{ml}$ in both milling times for this combination (Figure 9). 


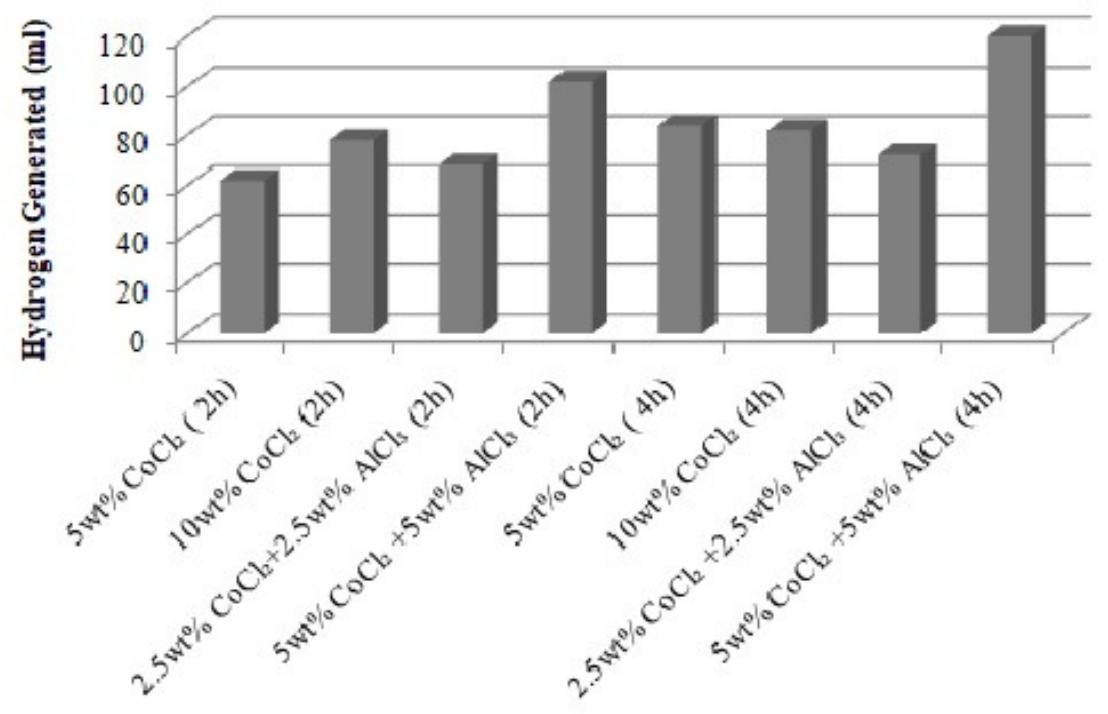

Figure 9. Hydrogen generation with $0.12 \mathrm{~g}$ of powder and $30 \mathrm{ml}, 2 \mathrm{M}$ acetic acid solution.

As can be seen in Figure 10, the best result obtained with a citric acid concentration of $2 \mathrm{M}$ and $\mathrm{Mg}$-metal chloride composite containing $10 \mathrm{wt} \% \mathrm{CoCl}_{2}$ has been recorded as $138 \mathrm{ml}$. When the same experiments have been carried out in $1 \mathrm{M}$ citric acid solution, $106 \mathrm{ml}$ of hydrogen evolution has been observed (Figure 8). Another remarkable result has been noted as $134 \mathrm{ml}$ hydrogen production during experiments involving the $5 \mathrm{wt} \% \mathrm{CoCl}_{2}$ and $5 \mathrm{wt} \% \mathrm{AlCl}_{3}$ duo with 4 hours milling time. It may be also supported by these results that the increase in milling time increases hydrogen production. When the composite containing $10 \mathrm{wt} \% \mathrm{CoCl}_{2}$ with a milling time of 4 hours has been used, $12 \mathrm{ml}$ more hydrogen has been obtained than the same composite with 2 hours milling time. Whenever the results have been compared, it has been seen that doubling the organic acid concentration has been contributed to the increase in the amount of hydrogen obtained.

It may be understood that samples containing only $5 \mathrm{wt} \%$ metal chloride in total have not been efficient in hydrogen production processes. But they may be supportive data to create comparisons. It may be noted that citric acid solution takes a more active role. The increase in weight percentages of metal chlorides in $\mathrm{Mg}$-metal chloride composites and the use of $\mathrm{CoCl}_{2}$ and $\mathrm{AlCl}_{3}$ together provided remarkable results in terms of the efficiency of the process. 


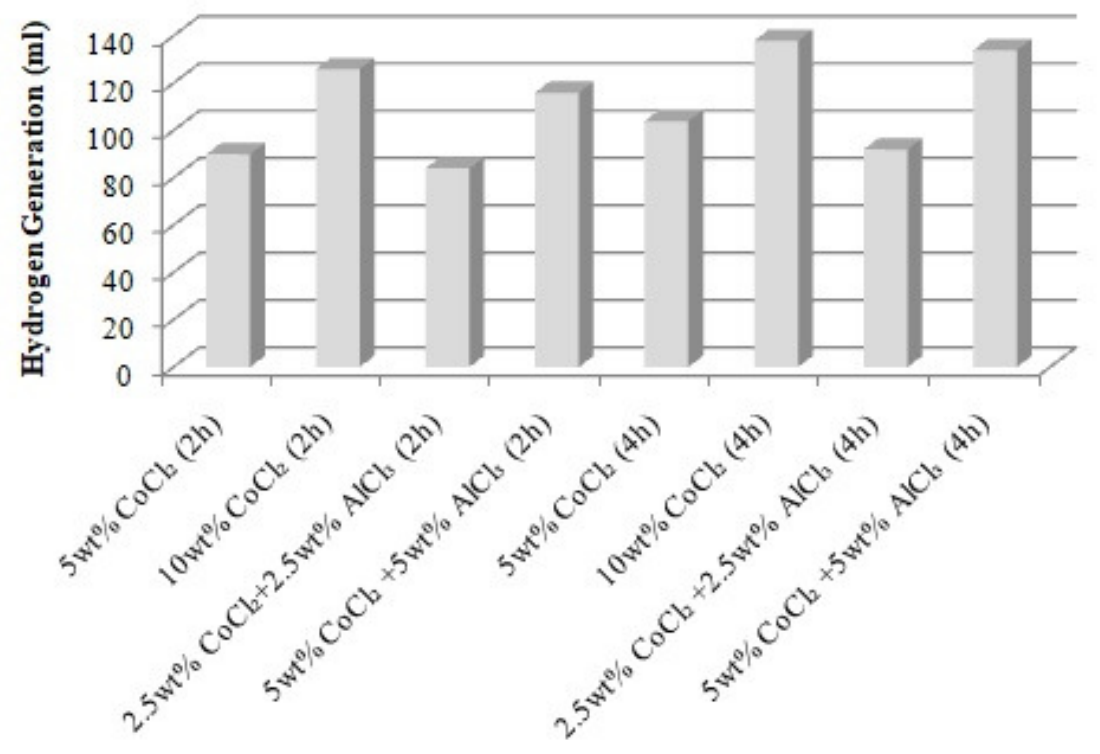

Figure 10. Hydrogen generation with $0.12 \mathrm{~g}$ of powder and $30 \mathrm{ml}, 2 \mathrm{M}$ citric acid solution.

\section{CONCLUSIONS}

To use $\mathrm{Mg}$ more effectively in $\mathrm{H}_{2}$ production, surface properties should be improved. For this purpose, in our study, the preparation of Mg-metal chloride composite has been carried out by ball milling. To make the hydrolysis medium more conductive, acetic acid and citric acid solutions (1 and $2 \mathrm{M}$ ) have been used and the effect on hydrogen gas production has been investigated. It may be appropriate to use environmentally friendly acetic acid and citric acid as a catalyst with $\mathrm{Mg}$-metal composites in the hydrogen generation reaction. In addition, the use of acetic acid and citric acid may further reduce the cost of hydrogen production. The results showed that $\mathrm{CoCl}_{2}$ and $\mathrm{AlCl}_{3}$ addition increased the reactivity and hydrogen generation amounts. Also, the use of $\mathrm{CoCl}_{2}$ and $\mathrm{AlCl}_{3}$ together improved the hydrogen generation rates and performances. $\mathrm{Mg}$-metal chlorides are very promising for hydrogen production applications.

\section{REFERENCES}

[1] Zhang, J. (2008). Hydrogen production by biomass gasification in supercritical water, Energeia, 19: 1-5.

[2] Kaneko, H., Miura, T., Ishihara, H., Taku, S., Yokoyama, T., Nakajima, H., Tamaura, Y. (2007). Reactive ceramics of $\mathrm{CeO}_{2}-\mathrm{MO}_{\mathrm{x}}(\mathrm{M}=\mathrm{Mn}, \mathrm{Fe}, \mathrm{Ni}, \mathrm{Cu})$ for $\mathrm{H}_{2}$ generation by two-step water splitting using concentrated solar thermal energy, Energy, 32: 656-663.

[3] Fan, M.Q., Liu, S.S., Zhang, Y., Sun, L.X., Xu, F. (2010). Superior hydrogen storage properties of $\mathrm{MgH}_{2}-10$ wt\% TiC composite, Energy, 35: 3417-3421.

[4] Yolcular, S., Karaoglu, S. (2017). Activation of Al powder with NaCl-assisted milling for hydrogen generation, Energy Sources, Part A: Recovery, Utilization and Environmental Effects, 39(18): 1919-1927.

[5] Wang, M., Ouyang, L., Zeng, M., Liu, J., Peng, C., Shao, H., Zhu, M. (2019). Magnesium borohydride hydrolysis with kinetics controlled by ammoniate formation, International Journal of Hydrogen Energy, 44: 7392-7401.

[6] Lalaurette, E., Thammannagowda, S., Mohagheghi, A., Maness, P.C. ve Logan, B.E. (2009). Hydrogen production from cellulose in a two-stage process combining fermentation and electrohydrogenesis, International Journal of Hydrogen Energy, 34: 6201-6210. 
[7] Barbir, F., Ulgiati, S. (2008). Sustainable Energy Production and Consumption, Springer, Dordrecht, Holland, 372.

[8] Yu, S.H., Uan, J.Y., Hsu, T.L. (2012). Effects of concentrations of $\mathrm{NaCl}$ and organic acid on generation of hydrogen from magnesium metal scrap, International Journal of Hydrogen Energy, 37: 3033-3340.

[9] Youssef, E.A., Nakhla, G. ve Charpentier, P.A. (2011). Oleic acid gasification over supported metal catalysts in supercritical water: hydrogen production and product distribution, International Journal of Hydrogen Energy, 36: 4830-4842.

[10] Uan, J.Y., Yu, S.H., Lin, M.C., Chen, L.F., Lin, H.I. (2009). Evolution of hydrogen from magnesium alloy scraps in citric acid-added seawater without catalyst, International Journal of Hydrogen Energy, 34: 61376142.

[11] Sun, Q., Zou, M., Guo, X., Yang, R., Huang, H., Huang, P., He, X. (2014). A study of hydrogen generation by reaction of an activated $\mathrm{Mg}-\mathrm{CoCl}_{2}$ (magnesium-cobalt chloride) composite with pure water for portable applications, Energy, 79: 310-314.

[12] Ouyang, L., Ma, M., Huang, M., Duan, R., Wang, H., Sun, L., Zhu, M. (2015). Enhanced Hydrogen Generation Properties of $\mathrm{MgH}_{2}$-Based Hydrides by Breaking the Magnesium Hydroxide Passivation Layer, Energies, 8: 4232-4257.

[13] Tan, Z.H., Ouyang, L.Z., Huang, J.M., Liu, J.W., Wang, H., Shao, H.Y., Zhu, M. (2019). Hydrogen generation via hydrolysis of $\mathrm{Mg}_{2} \mathrm{Si}$, Journal of Alloys and Compounds, 770: 108-115.

[14] Liu, Y., Wang, X., Dong, Z., Liu, H., Li, S., Ge, H., Yan, M. (2013). Hydrogen generation from the hydrolysis of $\mathrm{Mg}$ powder ball-milled with $\mathrm{AlCl}_{3}$, Energy, 53: 147-152.

[15] Weng, B., Wu, Z., Li, Z., Yang, H. (2012). Hydrogen generation from hydrolysis of $\mathrm{NH}_{3} \mathrm{BH}_{3} / \mathrm{MH}(\mathrm{M}=\mathrm{Li}$, $\mathrm{Na}$ ) binary hydrides, International Journal of Hydrogen Energy, 37: 5152-5160.

[16] Singh, P.K., Das, T. (2017). Generation of hydrogen from $\mathrm{NaBH}_{4}$ solution using metal-boride $(\mathrm{CoB}, \mathrm{FeB}$, $\mathrm{NiB}$ ) catalysts, International Journal of Hydrogen Energy, 42: 29360-29369.

[17] Leng, H., Xu, J., Jiang, J., Xiao, H., Li, Q., Chou, K.C. (2015). Improved dehydrogenation properties of $\mathrm{Mg}\left(\mathrm{BH}_{4}\right)_{2} \cdot 2 \mathrm{NH}_{3}$ combined with $\mathrm{LiAlH}_{4}$, International Journal of Hydrogen Energy, 40: 8362-8367.

[18] Figen, A.K., Coskuner, B. (2015). Hydrogen production by the hydrolysis of milled waste magnesium scraps in nickel chloride solutions and nickel chloride added in Marmara Sea and Aegean Sea Water, International Journal of Hydrogen Energy, 40(46): 16169-16177.

[19] Figen, A.K., Coskuner, B., Piskin, S. (2015). Hydrogen generation from waste Mg based material in various saline solutions $\left(\mathrm{NiCl}_{2}, \mathrm{CoCl}_{2}, \mathrm{CuCl}_{2}, \mathrm{FeCl}_{3}, \mathrm{MnCl}_{2}\right)$, International Journal of Hydrogen Energy, 40: 7483 7489.

[20] Oz, C., Filiz, B.C., Figen, A.K. (2017). The effect of vinegar- acetic acid solution on the hydrogen generation performance of mechanochemically modified magnesium (Mg) granules, Energy, 127: 328-334.

[21] Grosjean, M.H., Roué, L. (2006a), Hydrolysis of Mg-salt and $\mathrm{MgH}_{2}$-salt mixtures prepared by ball milling for hydrogen production, Journal of Alloys and Compounds, 416: 296-302.

[22] Ho, Y.S. (2013). Hydrogen Generation from Magnesium Hydride By Using Organic Acid, MSc Thesis, University of Wisconsin, Milwaukee.

[23] PubChem, "Magnesium Acetate", https://pubchem.ncbi.nlm.nih.gov/compound/8896, (Date of Access: 08.01.2021).

[24] Pubchem, "Magnesium Citrate”, https://pubchem.ncbi.nlm.nih.gov/compound/6099959 (Date of Access: 08.12.2021).

[25] Uda, M., Okuyama, H., Suzuki, T.S., Sakka, Y. (2012). Hydrogen generation from water using Mg nanopowder produced by arc plasma method, Science and Technology of Advanced Materials, 13: 1-7.

[26] Grosjean, M.H., Zidoune, M., Roué, L., Huot, J.Y. (2006b). Hydrogen production via hydrolysis reaction from ball-milled Mg-based materials, International Journal of Hydrogen Energy, 31: 109-119.

[27] Aytaş, B.E. (2019). The use of Mg-metal chloride composites in hydrogen production, MSc The $i \square$, Ege Univer ity Graduate School of Applied and Natural Science, İzmir. 
[28] Wang, S, Sun, L.X., Xu, F., Jiao, C.L., Zhang, J., Zhou, H.Y., Huang, F.L. (2012). Hydrolysis reaction of ball-milled $\mathrm{Mg}$-metal chlorides composite for hydrogen generation for fuel cells, International Journal of Hydrogen Energy, 37: 6771-6775.

[29] Tian, M., Shang, C. (2019). Mg-based composites for enhanced hydrogen storage performance, International Journal of Hydrogen Energy, 44: 338-342.

[30] Cho, C., Wang, K., Uan, J. (2005). Evaluation of a new hydrogen generating system: Ni-rich magnesium alloy catalyzed by platinum wire in sodium chloride solution, Materials Transactions, 46: 2704-2708.

[31] Zhao, Z.W., Chen, X.Y., Hao, M.M. (2011). Hydrogen generation by splitting with Al-Ca alloy, Energy, 36 : 2782-2787. 